\title{
Utilisation de la cotinine contenue dans les cheveux comme marqueur d'une exposition à la fumée de tabac. Méta-analyse d'études internationales
}

\section{Benchmarking hair cotinine as a marker of tobacco smoke exposure. Meta-analysis of international studies}

\section{Ana FLORESCU, Gideon KOREN*, Julia KLEIN, Joey GARERI}

Department of Public Healt Sciences, Department of Pharmacology, University of Toronto - Canada

*Corresponding Author: Gideon KOREN, MD, FRCPC Director, Motherisk Program Division of Clinical Pharmacology and Toxicology, Hospital for Sick Children, 555, University Avenue - Toronto - Ontario - Canada M5G 1X8 - Phone : (416) 813-5781 - Fax: (416) 813-7562 - E-mail: gkoren@ sickkids.ca

(Reçu le 7 novembre 2005 ; accepté le 17 décembre 2005)

\section{RÉSUMÉ}

Au cours des 12 demières années, nous avons établi et validé l'utilisation de la cotinine contenue dans les cheveux comme marqueur de l'exposition à la fumée de tabac. Cette méta-analyse, réalisée à partir de toutes les études disponibles de notre laboratoire et d'autres centres, est destinée à établir des valeurs de cotinine dans les cheveux, dans le contexte de l'exposition fatale à la fumée de tabac environnante. Les valeurs ci-dessous ont été mesurées sur plus de 1000 patients :

$\begin{array}{lcc}\text { Sujets } & \text { cotinine }(\mathrm{ng} / \mathrm{mg}) & 95 \% \text { IC } \\ \text { FEMMES NON ENCEINTES } & \\ \text { Fumeuses actives } & 2.72 & 2.32-3.13 \\ \text { Fumeuses passives } & 0.62 & 0.51-0.74 \\ \text { Non exposées } & 0.29 & 0.23-0.36 \\ \text { FEMMES ENCEINTES } & & \\ \text { Fumeuses actives } & 1.7 & 1.46-1.94 \\ \text { Fumeuses passives } & 0.07 & 0-0.09 \\ \text { Non exposées } & 0.08 & 0-0.09\end{array}$

\section{SUMMARY}

Over the last 12 years we established and validated the use of hair cotinine as a biomarker of exposure to tobacco smoke. This meta analysis of all available studies from our laboratory and other centers, aimed at establishing values of hair cotinine in the context of fetal exposure to environmental tobacco smoke. The following are the values arrived at with over 1000 patients:

$\begin{array}{lcc}\begin{array}{l}\text { Subjects } \\ \text { NON PREGNANT WOMEN }\end{array} & 95 \% \mathrm{CI} \\ \text { active smokers } & 2.72 & \\ \text { passive smokers } & 0.62 & 2.32-3.13 \\ \text { unexposed } & 0.29 & 0.51-0.74 \\ \text { PREGNANT WOMEN } & & 0.23-0.36 \\ \text { Active smokers } & 1.7 & \\ \text { Passive smokers } & 0.07 & 1.46-1.94 \\ \text { Unexposed } & 0.08 & 0-0.09 \\ \text { CHILDREN } & & 0-0.09 \\ \text { Passive } & 0.96 & 0.86-1.07\end{array}$




$\begin{array}{lcc}\text { ENFANTS } & & \\ \text { Passifs } & 0.96 & 0.86-1.07 \\ \text { Non exposés } & 0.33 & 0.25-0.4 \\ \text { NOUVEAU-NÉS } & & \\ \text { Exposés in utéro } & 1.42 & 1.18-1.65\end{array}$

La séparation entre les différents états d'exposition avec un intervalle de confiance à $95 \%$ devrait pouvoir faciliter les recherches, ainsi que les cas cliniques où une exposition passive peut être dangereuse (par exemple des enfants avec de l'asthme vivant dans une maison de fumeurs) et aider l'assurance maladie.

\section{Introduction}

Active and passive smoking have been associated with an array of adverse effects on health. The development of valid and accurate scales of measurement for exposures associated with health risks constitutes an active area of research. Tobacco smoke exposure still lacks an ideal method of measurement. Because relying on selfreport and the various biases it introduces may lead to inaccurate measures of nicotine exposure, more objective solutions have been suggested.

A valid estimation of the risks associated with tobacco exposure depends on accurate measurement. However, some groups of people are more reluctant than others to disclose their smoking status and exposure to tobacco. This is particularly true for pregnant women and parents of young children, whose smoking is often regarded as socially unacceptable. Despite well-documented adverse effects, tobacco remains one of the two most popular legal drugs used by pregnant women, second only to alcohol. Approximately $11 \%$ of pregnant Canadian women are active smokers (1). As this estimate is based on self-reported information, it may underestimate the true prevalence. The approximate proportion of non-smoking pregnant women exposed to ETS from their spouse is $12 \%$ (1). The risks to the neonate and infant associated with maternal smoking include preterm birth, intrauterine growth retardation, low birth weight, perinatal and neonatal mortality, sudden infant death syndrome and possibly congenital malformations. In children, ETS exposure is one of the most common and hazardous environmental exposures known. The annual excess in deaths of children five years of age or younger due to exposure to ETS is believed to exceed those due to all injuries combined (2). The long-term effects of ETS exposure in children range from respiratory conditions, to neurotoxic consequences (3-7).

Biomarkers constitute the most commonly used objective method of ascertaining nicotine exposure. Of those available, cotinine has gained supremacy as the biomarker of choice. Traditionally, cotinine has been mea-
Unexposed $\quad 0.33$

NEONATES

1.42

$0.25-0.4$

Exposed in utero

$1.18-1.65$

The clear $95 \%$ confidence interval separation between the different states of exposure may facilitate research, as well as clinical cases where passive exposure can be life threatening (eg children with asthma in homes of smokers), and in health insurance.

sured in blood, saliva and urine. Cotinine collection and analysis from these sources has posed some difficulties, which have motivated the search for a more consistent and reliable source of this biomarker.

Hair analysis is a novel, non-invasive technique used to detect the presence of drugs and metabolites in the hair shaft. Because cotinine accumulates in hair during hair growth, it is a unique measure of long-term, cumulative exposure to tobacco smoke. Although hair analysis of cotinine holds great promise, a detailed evaluation of its potential as a biomarker of nicotine exposure, is needed. No studies have been published that address this issue. Because the levels of cotinine in the body are dependent on nicotine metabolism, which in turn is affected by factors such as age, pregnancy, breathing rates, and so forth, the characterization of hair cotinine should be population-specific.

In contrast to nicotine, cotinine in the hair is found at much lower concentrations (8) and reflects only systemic exposure (9), as opposed to nicotine which is deposited in the hair shaft both systemically during hair synthesis and by uptake from atmospheric exposure (10). Reported values of hair cotinine range from 0.01 to $0.3 \mathrm{ng} / \mathrm{mg}$ for unexposed individuals; from 0.01 to $0.94 \mathrm{ng} / \mathrm{mg}$ for individuals exposed to ETS; and from 0.09 to $6.3 \mathrm{ng} / \mathrm{mg}$ for active smokers (11-20).

This study is the first to define ranges of hair cotinine as a biomarker of active and passive smoking among women of reproductive age, pregnant women, children and neonates.

\section{Experimental Hair Collection}

Hair was collected from mothers, pregnant women, neonates and children at various stages. For mothers and their children, hair was collected simultaneously during the clinic visit (studies \#1 and \#5). Children's hair was collected during parental survey administration (study \#4). In study \#6, neonatal and maternal hair was cut at birth. Pregnant women donated their hair at 
birth as well in study \#2 and \#3. About 30 strands of hair were cut from the vertex posterior region of the scalp. Hair samples were placed in a thin envelope, labeled, sealed, and sent to the Clinical Pharmacology and Toxicology Laboratory at the Hospital for Sick Children in Toronto, Ontario, Canada.

\section{Hair Analysis}

In cases where segmental analysis was performed (studies \#2 and \#3), hair was sectioned starting at the root end, based on an estimated growth rate of one centimeter per month into three segments each measuring about three centimeters, corresponding to the three trimesters.

Approximately 2-7 mg of hair was weighed on an analytical balance and placed in a glass vial. Hair was minced and digested with $1 \mathrm{~mL}$ of $0.6 \mathrm{~N}$ sodium hydroxide. Samples were covered with parafilm to prevent evaporation, agitated and incubated overnight at $50^{\circ} \mathrm{C}$. Samples were neutralized the following morning, with 50-70 $\mu \mathrm{L}$ concentrated hydrochloric acid to $\mathrm{pH} 7.4$.

The concentration of cotinine in $0.1 \mathrm{~mL}$ samples was measured by a highly specific radioimmunoassay using monoclonal antibodies described by Langone (21).

The reagents for the assay were obtained from the Department of Biochemistry, Brandeis University, Waltham, MA, U.S. The cotinine assays used isogeltris buffer (trimethamine hydrochloride, $0.14 \mathrm{mmol} / \mathrm{L}$, sodium chloride, $0.14 \mathrm{mmol} / \mathrm{L}$, and $0.1 \%$ gelatin; $\mathrm{pH}$ 7.4). The radioimmunoassay involved adding fixed amounts of sample tritiated cotinine and their respective antiserum raised in rabbits. The samples were subsequently incubated in a shaker for 1 hour at $37^{\circ} \mathrm{C}$. A sufficient amount of antibody was added to bind a maximum of 40-50\% of the radioactive ligand for optimal results. Following incubation, a goat anti-rabbit $\gamma$ globulin was added to separate the antibody-bound fraction from the free analyte. To control for non-specific binding normal rabbit serum was used in place of the specific antibody.

The samples were then incubated overnight at $4^{\circ} \mathrm{C}$. Samples were centrifuged at $1000 \mathrm{~g}$ for 1 hour at $4^{\circ} \mathrm{C}$ the following day. The non-precipitated fraction was decanted, and the sides of the scintillation tubes were cleaned using cotton tip pipe cleaners to remove any residual radioactivity. The precipitated fraction was redissolved in $0.1 \mathrm{~mL}$ of $0.1 \mathrm{~N}$ sodium hydroxide. Finally, $2.5 \mathrm{~mL}$ of Beckman scintillation fluid was added to each sample. The amount of radioactivity was measured in a Beckmann LS $5000 \mathrm{CE}$ scintillation counter and expressed as average counts per minute. A counting time of two minutes was used for all samples. The concentration of each sample was determined by comparison to a standard curve for cotinine. The standard curve was prepared at the same time and in the same manner as the samples, in order to account for inter-day variability and decay of the isotope. For quantification, cotinine standards of 0.1 to $20 \mathrm{ng} / \mathrm{mL}$ were used. To ensure quality control and for reference, negative and positive controls were used. The detection limit for this assay was $0.02 \mathrm{ng} / \mathrm{mg}$ of hair when $5 \mathrm{mg}$ of hair was used for analysis. The cross reactivity of nicotine in the cotinine assay was measured at $5 \%$. The major metabolite of cotinine is trans-3'-hydroxy-cotinine. The cross reactivity of trans-3'-hydroxy-cotinine in the cotinine assay was only $2 \%$. Recovery values for cotinine were established by adding known amounts of cotinine to a negative hair sample after digestion. Aliquots of the spiked solution were analyzed and recovery was calculated. A recovery value of $92 \%$ for cotinine was calculated on the basis of six experiments.

\section{Calculations for cotinine}

The radioactivity or counts per minute were corrected for non-specific binding and expressed as a percent of the maximum binding. The standard curve was created using linear regression by plotting the logit of the percent bound (i.e., In [\%-bound $/(1$ - \%-bound)]) versus the natural $\log$ of the standard concentration. The equation of the regression line was used to identify the concentrations of the unknown solutions. The unknown concentrations were calculated by solving for variable $x$ in the linear equation $y=b_{0}+b_{1} x$, where $x=\log$ [cotinine] and $y=\operatorname{logit}$ ( $\%$ bound). The final results were expressed in nanograms of cotinine per milligram of hair.

\section{Methods}

\section{Sources of data}

Six available studies exhibiting hair measurements of cotinine in heterogeneous populations of pregnant women, women of reproductive age, children and neonates were analyzed. Because previous reports have demonstrated higher urine and hair cotinine concentrations in asthmatic children compared to non-asthmatics, studies measuring hair cotinine in asthmatics were excluded from this analysis (22). Permission to access the individual patient data was obtained from the respective authors. Data were stored in databases in SPSS format. The details of recruitment and enrolment for each study utilized are presented below (see Table I). 
Table I : Characteristics of included studies: study location and year of data collection, study design, target population, sampling techniques, inclusion and exclusion criteria.

\begin{tabular}{|c|c|c|c|c|c|c|c|c|}
\hline Study & $\begin{array}{l}\text { Study } \\
\text { Location }\end{array}$ & $\begin{array}{l}\text { Study } \\
\text { Recruitment } \\
\text { Period }\end{array}$ & Study design & Target population & $\begin{array}{l}\text { Sampling } \\
\text { technique }\end{array}$ & Inclusion criteria & $\begin{array}{l}\text { Exclusion } \\
\text { criteria }\end{array}$ & $\begin{array}{l}\text { Smoking } \\
\text { and ETS } \\
\text { exposure }\end{array}$ \\
\hline $\begin{array}{l}\text { 1. Grossman } \\
\text { (unpublished) }\end{array}$ & $\begin{array}{l}\text { Baltimore, } \\
\text { MD, U.S. }\end{array}$ & $2002-2004$ & $\begin{array}{l}\text { Descriptive } \\
\text { survey }\end{array}$ & $\begin{array}{l}\text { Mothers of young } \\
\text { children; } \\
\text { Children aged } 2 \\
\text { weeks to } 5 \text { years } \\
\text { visiting an inner } \\
\text { city hospital }\end{array}$ & $\begin{array}{l}\text { Convenience } \\
\text { sample from } \\
\text { Pediatric Centre } \\
\text { of the } \\
\text { University of } \\
\text { Maryland }\end{array}$ & $2-5$ years of age & $\begin{array}{l}\text { Chronic } \\
\text { pulmonary } \\
\text { disease }\end{array}$ & $\begin{array}{l}\text { Mother's } \\
\text { smoking } \\
\text { status; } \\
\text { child's ETS. }\end{array}$ \\
\hline $\begin{array}{l}\text { 2. Cole } \\
\text { (unpublished) }\end{array}$ & $\begin{array}{l}\text { Boston, MA, } \\
\text { U.S. }\end{array}$ & 2003 & Cross-sectional & $\begin{array}{l}\text { Pregnant women } \\
\text { and their infants }\end{array}$ & $\begin{array}{l}\text { Hospital } \\
\text { convenience } \\
\text { sample }\end{array}$ & $\begin{array}{l}\geq 35 \text { weeks GA at } \\
\text { delivery. }\end{array}$ & & $\begin{array}{l}\text { Mother's } \\
\text { smoking } \\
\text { status and } \\
\text { ETS. }\end{array}$ \\
\hline 3. Kramer (33) & $\begin{array}{l}\text { Montreal, } \\
\text { QC, Canada }\end{array}$ & $1999-2002$ & $\begin{array}{l}\text { Case-control } \\
\text { nested in a } \\
\text { prospective } \\
\text { cohort study }\end{array}$ & Pregnant women & $\begin{array}{l}\text { Hospital-based } \\
\text { sample } \\
\text { collected from } 4 \\
\text { Montreal } \\
\text { hospitals } \\
\\
=-\end{array}$ & $\begin{array}{l}\text { 18 years, } \\
\text { singleton } \\
\text { pregnancy }\end{array}$ & $\begin{array}{l}\text { Severe } \\
\text { chronic } \\
\text { illness, } \\
\text { placenta } \\
\text { previa, } \\
\text { incompetent } \\
\text { cervix, major } \\
\text { fetal anomaly }\end{array}$ & $\begin{array}{l}\text { Mother's } \\
\text { smoking } \\
\text { status, no } \\
\text { ETS. }\end{array}$ \\
\hline $\begin{array}{l}\text { 4. Woodruff } \\
\text { (34) }\end{array}$ & $\begin{array}{l}\text { San Diego, } \\
\text { CA, U.S. }\end{array}$ & 2003 & $\begin{array}{l}\text { Randomized } \\
\text { controlled trial }\end{array}$ & $\begin{array}{l}\text { Spanish-speaking } \\
\text { Latino children } \\
\text { aged } 1-9 \text { exposed } \\
\text { to ETS }\end{array}$ & $\begin{array}{l}\text { Recruitment } \\
\text { from } \\
\text { community } \\
\text { organizations } \\
\text { and venues } \\
\end{array}$ & $\begin{array}{l}\text { Hispanic/Latino, } \\
\text { child between 1-9 } \\
\text { years, child } \\
\text { exposed to ETS }\end{array}$ & & $\begin{array}{l}\text { Child's ETS } \\
\text { from } \\
\text { parental } \\
\text { report }\end{array}$ \\
\hline 5. Groner (35) & $\begin{array}{l}\text { Columbus, } \\
\text { OH, U.S. }\end{array}$ & $1997-2000$ & $\begin{array}{l}\text { Prospective } \\
\text { cohort }\end{array}$ & $\begin{array}{l}\text { Healthy children } \\
\text { aged } 2 \text { weeks to } 3 \\
\text { years, low income } \\
\text { and their mothers }\end{array}$ & $\begin{array}{l}\text { Convenience } \\
\text { sample recruited } \\
\text { from Columbus } \\
\text { Children's } \\
\text { Hospital }\end{array}$ & $\begin{array}{l}2 \text { weeks-3 years } \\
\text { and healthy } \\
\text { children }\end{array}$ & $\begin{array}{l}\text { Prematurity, } \\
\text { chronic } \\
\text { disease, }\end{array}$ & $\begin{array}{l}\text { Child's ETS } \\
\text { from } \\
\text { parental } \\
\text { report }\end{array}$ \\
\hline $\begin{array}{l}\text { 6. Jacqz-Aigrain } \\
\text { (36) }\end{array}$ & Paris, France & 2000 & $\begin{array}{l}\text { Prospective } \\
\text { cohort }\end{array}$ & $\begin{array}{l}\text { Pregnant smokers } \\
\text { and their newborns }\end{array}$ & $\begin{array}{l}\text { Convenience } \\
\text { sample recruited } \\
\text { at the Hôpital } \\
\text { Robert Debre, } \\
\text { Paris }\end{array}$ & & $\begin{array}{l}\text { Twin } \\
\text { pregnancy }\end{array}$ & $\begin{array}{l}\text { Mother's } \\
\text { smoking } \\
\text { status and } \\
\text { ETS. }\end{array}$ \\
\hline
\end{tabular}

\section{Exposure Measurements}

Smoking status and exposure to ETS were ascertained by questionnaire in each of the six studies. For this analysis, all six studies were combined. A classification system was established in order to categorize subjects from all studies into three exposure categories: active smokers, passive smokers and unexposed non-smokers.

Because previous studies have shown that nicotine metabolism is influenced by pregnancy, as well as by age, the analysis was stratified by subject type into the following four groups: 1) Non-pregnant women with children, 2) Pregnant women and those whose hair samples represent exposure during pregnancy (recent mothers who donated hair right after birth), 3) Neonates exposed in utero only (hair sample collected at birth) and 4) Children. Thus, after combining all studies, within each of the four subject groups, cases were further subdivided into the three tobacco exposure categories (see Figure 1).

The contributing studies have collected data on smoking exposure heterogeneously; similar categories between studies were matched as closely as possible.

For those studies measuring smoking exposure during each trimester, data pertaining to the third trimester were used exclusively. This is because fetal hair begins growth during the last trimester of pregnancy and will

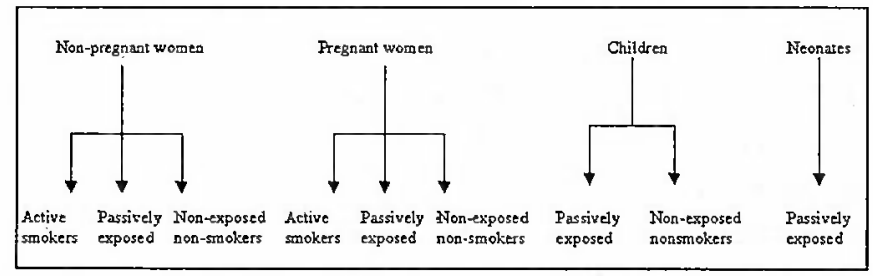

Figure 1 : Diagram of study groups constructed for hair cotinine analysis.

only reflect exposures during that time period (23).

Active smokers were defined as:

- Mothers admitting to smoking one or more cigarettes per day during the week before hair collection - Studies \#1 and \#5

- Pregnant women who reported smoking at least 1 cigarette per day during third trimester - Studies \#2, \#3 and \#6

Passive smokers were defined as:

- Mothers who smoked 0 cigarettes per day the week before interview but had frequent home visitors who smoked - Studies \#1 and \#5

- Children whose mothers were either active smokers, had frequent visitors who smoked, or whose daycare provider was a smoker - Studies \#1 and \#5 
- Pregnant women who reported smoking 0 cigarettes per day in all trimesters and who lived with people who smoked inside their home during pregnancy, or who worked inside where smoking was permitted, or who were exposed to second-hand smoke on a daily basis anywhere else - Studies \#2 and \#6

- Children whose parents reported child exposure to at least one cigarette in the past 30 days - Study \#4

- Neonates exposed in utero due to maternal smoking during third trimester or due to maternal exposure to ETS - Study \#6

Unexposed non-smokers were defined as:

- Mothers who smoked 0 cigarettes per day the week before interview and did not have frequent visitors who smoked - Studies \#1 and \#5

- Pregnant women who reported smoking 0 cigarettes per day in all trimesters and who had no reported second-hand smoke exposure - Studies \#2 and \#6

- Children whose parents reported no ETS exposure Studies \#1, \#5 and \#4

\section{Inclusion/Exclusion criteria}

To be included in the current analysis, clear categorization into one of the three tobacco exposure groups was required. Any case that did not have information (missing data) on one of the variables required to assign exposure status was excluded. In study \#3, no information on ETS exposure was collected; thus, from that study only active smokers were included. Only two neonates were classified as unexposed. Because they represented a special population, which needs separate analysis, these two were regarded as insufficient to form a proper group, and thus were excluded.

\section{Results}

\section{Characteristics of the studies used}

The studies used in this analysis were conducted in different locations in Canada, the U.S. and France between 1997 and 2003. Characteristics of women (pregnant and non-pregnant), infants exposed in utero (hair collection occurred within one week of birth) and children, as well as hair samples, were collected from a total of 1746 subjects, from different populations in Baltimore (Maryland), Columbus (Ohio), Boston (Massachusetts), Montreal (Quebec), Paris (France), San Francisco (California) and San Diego (California), representing a mix of ethnic backgrounds.

The average age of the subjects enrolled was similar among studies, ranging between 25-30 years for mothers, and between 6 months and 4 years for children. Table II describes comparative characteristics of the studies used in the current analysis.

\section{Hair cotinine distributions}

There were 1746 subjects selected for the final analysis based on classification criteria previously described, of which 540 were non-pregnant mothers, 424 were pregnant women, 202 were neonates exposed in utero and 580 children aged 2 weeks to 6 years. The exposure categories were comprised of 505 active smokers, 826 passive smokers and 415 unexposed non-smokers.

The mean hair cotinine and 95\% confidence intervals for non-pregnant women were 2.72 [2.32-3.13] for active smokers, $0.62[0.51-0.74]$ for passive smokers and 0.29 [0.23-0.36] for unexposed non-smokers. Because hair cotinine data did not follow a normal distribution, medians and geometric means are also reported as indicators of central tendency (Table 3). For the pregnant population mean hair cotinine was 1.70 [1.46-

Table II : Demographic characteristics of subjects, by study.

\begin{tabular}{|c|c|c|c|c|c|c|}
\hline Study & Year of data collection & Study Location & Total sample used (N) & Patient type & Age & Ethnicity/Populations represented \\
\hline $\begin{array}{l}\text { 1. Grossman } \\
\text { (unpublished) }\end{array}$ & 2002 & Baltimore & 307 & $\begin{array}{l}\text { Mothers } N=169 \\
\text { Children } N=138\end{array}$ & $\begin{array}{c}\text { Mother } \\
\text { (childbearing age) } \\
\text { Child 6-25 months } \\
\end{array}$ & $\begin{array}{c}88 \% \text { African } \\
\text { American } \\
\text { Low income } \\
\end{array}$ \\
\hline $\begin{array}{l}\text { 2. Cole } \\
\text { (unpublished) }\end{array}$ & 2001 & Boston & 143 & $\begin{array}{l}\text { Pregnant women } \\
\mathrm{N}=143\end{array}$ & Mean $=30$ years & $\begin{array}{l}58 \% \text { White } \\
22 \% \text { Asian } \\
13 \% \text { Black }\end{array}$ \\
\hline 3. Kramer(33) & 2001 & Montreal & 77 & $\begin{array}{l}\text { Pregnant women } \\
\mathrm{N}=77\end{array}$ & $\begin{array}{c}\text { Childbearing age } \\
\text { age }>18\end{array}$ & $\begin{array}{c}\text { Mixed, wide SES } \\
\text { spectrum }\end{array}$ \\
\hline 4. Woodruff(34) & 2003 & San Diego & 115 & Children $N=115$ & Mean $=4$ years & $\begin{array}{c}\text { Hispanic/Latino population, } \\
\text { low income }\end{array}$ \\
\hline 5. Groner(35) & $1997-2000$ & Ohio & 698 & $\begin{array}{l}\text { Mothers } N=371 \\
\text { Children } N=327\end{array}$ & $\begin{array}{l}\text { Mothers }=24.9 \text { years } \\
\text { Children }=1.3 \text { years }\end{array}$ & $\begin{array}{c}43 \% \text { white } \\
45 \% \text { African-American, Low income }\end{array}$ \\
\hline $\begin{array}{l}\text { 6. Jacqz-Aigrain } \\
\text { (36) }\end{array}$ & 2000 & Paris & 406 & $\begin{array}{c}\text { Mothers (recent) } \\
\qquad \mathrm{N}=204 \\
\text { Neonates } \mathrm{N}=202\end{array}$ & Mothers $=30.9$ years & $\begin{array}{l}\text { Urban French pregnant } \\
\text { population }\end{array}$ \\
\hline
\end{tabular}


Annales de Toxicologie Analytique, vol. XVII, $\mathrm{n}^{\circ}$ 4, 2005

Table III : Descriptive statistics for hair cotinine by exposure status and subject group.

\begin{tabular}{|c|c|c|c|c|c|c|c|c|c|}
\hline Population/Exposure group & $\mathrm{N}$ & Mean HC & SD & Variance & SE & $95 \%$ Cr of the mean & Median & Geometric Mean & Range \\
\hline \multicolumn{10}{|l|}{ Non-pregnant mothers } \\
\hline Active & 215 & 2.72 & 2.99 & 8.95 & 0.20 & $2.32-3.13$ & 1.82 & 1.63 & $0.03-19.85$ \\
\hline Passive & 150 & 0.62 & 0.72 & 0.51 & 0.06 & $0.51-0.74$ & 0.40 & 0.35 & $0.00-3.80$ \\
\hline Unexposed & 175 & 0.29 & 0.45 & 0.20 & 0.03 & $0.23-0.36$ & 0.15 & 0.16 & $0.00-3.65$ \\
\hline \multicolumn{10}{|l|}{ Pregnant women } \\
\hline Active & 290 & 1.70 & 2.06 & 4.26 & 0.12 & $1.46-1.94$ & 1.09 & 1.01 & $0.04-18.36$ \\
\hline Passive & 22 & 0.07 & 0.06 & 0.003 & 0.01 & $0.04-0.09$ & 0.06 & 0.05 & $0.01-0.22$ \\
\hline Unexposed & 112 & 0.08 & 0.08 & 0.01 & 0.01 & $0.06-0.09$ & 0.06 & 0.05 & $0.01-0.45$ \\
\hline \multicolumn{10}{|l|}{ Children } \\
\hline Passive & 452 & 0.96 & 1.16 & 1.36 & 0.05 & $0.86-1.07$ & 0.53 & 0.48 & $0.00-8.18$ \\
\hline Unexposed & 128 & 0.33 & 0.42 & 0.17 & 0.04 & $0.25-0.40$ & 0.17 & 0.19 & $0.00-3.12$ \\
\hline \multicolumn{10}{|l|}{ Neonates } \\
\hline Passive & 202 & 1.42 & 1.68 & 2.84 & 0.12 & $1.18-1.65$ & 1.07 & 1.00 & $0.12-16.0$ \\
\hline
\end{tabular}

1.94] for active smokers, 0.07 [0.04-0.09] for passive smokers and 0.08 [0.06-0.09] for unexposed non-smokers. Passively exposed children had a mean hair cotinine of 0.96 [0.86-1.07] compared to unexposed children whose mean was 0.33 [0.25-0.40]. Passively exposed neonates had a mean hair cotinine of 1.42 [1.181.65] (Table 3).

Median hair cotinine were highest in the non-pregnant active smokers, followed by the active pregnant smokers and passively exposed neonates. In each subject group hair cotinine was lowest in the unexposed, higher in the passively exposed and highest in the active smokers (Figure 2).

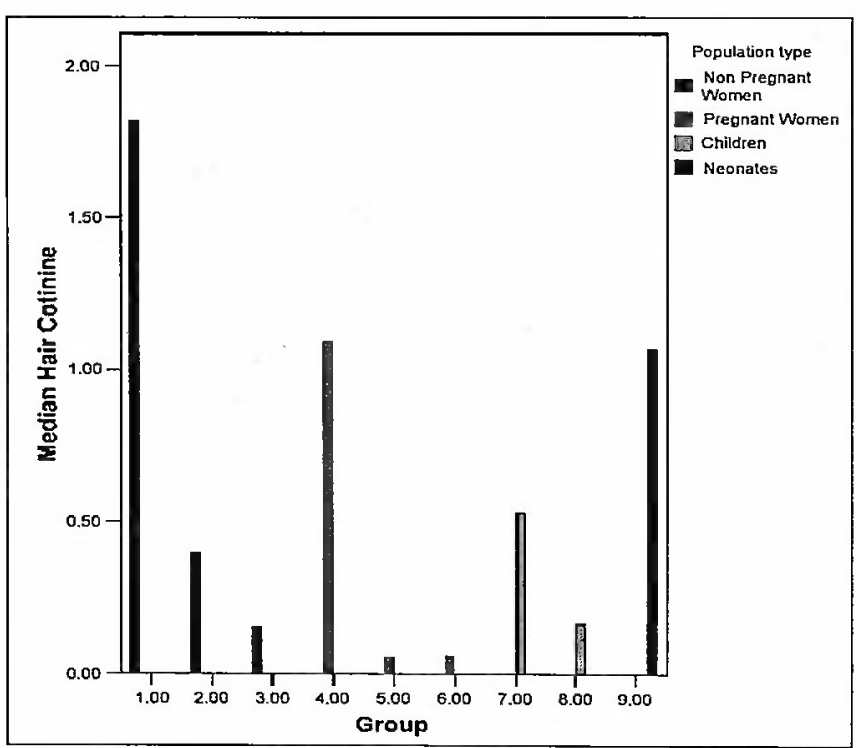

Figure 2 : Median hair cotinine by ETS exposure statuts and group type; Group 1 = non-pregnant women, active smokers; Group 2 = non-pregnant women; passilely exposed; Group 3 = non-pregnant women, unexposed; Group $4=$ pregnant women, active smokers; Group 5 = pregnant women, passively exposed; Group $6=$ pregnant women, unexposed, Group $7=$ children, passively exposed; Group $8=$ children, unexposed; Group $9=$ neonate, passively exposed.

\section{Discussion}

\section{Hair cotinine trends}

The hair cotinine trends observed in this study are consistent with the self-reported information on smoking status and exposure to ETS. In all age groups, hair cotinine was higher in the active smokers compared to passive smokers, and higher in the passive group than in the unexposed. This trend was inconsistent in only one group, the passively exposed pregnant women. We attribute this inconsistency to the low number of case in this group $(\mathrm{N}=22)$, which made a precise estimation of mean hair cotinine difficult.

Pregnant women had lower hair cotinine concentrations than non-pregnant women of reproductive age for all three levels of exposure. Lower mean cotinine values have been reported in the pregnant population compared to non-pregnant women (24). In the current study this was confirmed after adjusting for reported tobacco consumption (hair cotinine per cigarette). This observation may be due to a number of factors that were not analyzed, and include: underreporting of tobacco consumption among the non-pregnant women, switching to lower yield cigarettes during pregnancy, length of inhalation, manner of smoking, decreased amount of smoking during pregnancy, or different pharmacokinetics of cotinine during pregnancy. Some authors have suggested altered metabolism of cotinine in pregnancy $(25,26)$ with increased rates of cotinine clearance in pregnant women (27). This cautions us to select cut off values specific for the pregnant population, as the lower hair cotinine values observed do not necessarily reflect reduced exposure. Correctly identifying exposure in pregnant women is important due to the fetal implications associated with tobacco exposure. 
A significantly higher hair cotinine concentration was also observed in passively exposed neonates compared to passively exposed children. Higher actual exposure in the neonates seems unlikely, as children have more sources of exposure than neonates who are only exposed to maternal uptake of nicotine: The U.S. EPA report indicates that cotinine half-life is typically longer in neonates (10). Higher cotinine values in the youngest age groups have been reported in previous studies (28$30)$.

\section{Improving ETS exposure measurement}

In the absence of a standardized questionnaire measuring ETS exposure, and a lack of a standard with which to validate the questionnaires, epidemiologic studies that attempt to measure the association between active smoking or ETS exposure and health outcomes must rely on other methods to obtain the most accurate exposure data possible.

Currently, no biomarker of active smoking or ETS exposure can be taken as a perfect index of real exposure. Some authors suggest a combination of carefully worded self-reported questionnaire (interviewer-administered is preferable) and measured cotinine values in hair. To improve the validity of self-report careful attention must be paid to the wording of those questions measuring exposure, the sequence of questions, the manner of administration of the questionnaire, and use of the bogus pipeline effect.

To improve the performance of cotinine as a biomarker of ETS exposure, simultaneous analysis of two biomarkers could be useful. Torano found that correct classification occurred in $93 \%$ of cross-validated grouped cases when using two biomarkers (saliva nicotine and cotinine) (31). Simultaneous identification of more than one biomarker is facilitated by existing laboratory methods, permitting concurrent analysis of multiple markers (31).

Despite the difficulty of pooling data collected heterogeneously from different studies, there is a main advantage to the current design. Because data were collected at different times, locations, areas and from different ethnic groups, they are more likely, as an aggregate, to represent the larger obstetric population. The finding that mean hair cotinine among these diverse individuals was not heterogeneous, lends support to the generalizability of the overall findings.

\section{Applications}

Validation of hair cotinine as a biomarker of active smoking and ETS exposure will have great utility in view of the long-term window of exposure that this biomarker offers. Cotinine and nicotine from body fluids have short half-lives which render them uninformative in assessing long-term exposure, while cotinine in hair is available indefinitely if the hair is not cut. Hair cotinine could prove useful in a cessation program, where assessment of abstinence is currently done weekly, both a costly and time-consuming procedure. Because hair cotinine offers the possibility of segmental hair analysis, which assesses exposure over a given period of time, abstinence could be verified by measuring hair cotinine in the proximal one centimeter of hair and comparing it to the established cut-off for a non-smoker.

Another application of hair cotinine analysis is in the ascertainment of fetal exposure to ETS. Because hair grows in the last trimester, and metabolized cotinine passes from maternal to fetal circulation and from there gets incorporated into fetal hair, analysis of newborn hair has the potential to reveal exposure to ETS, both from active maternal smoking as well as from maternal exposure to second hand smoke. Risk assessment of fetal illness associated with ETS exposure relies on the accurate measurement of fetal exposure, which was nearly impossible to achieve prior to hair analysis.

Although some reviews suggest that questionnaires may be sufficiently accurate and consistent for population-based studies, and the cost of validating self-report with biochemical data may be too restrictive, in the pediatric-relevant setting, validation of parental report of child exposure, as well as self-report on smoking habits by pregnant women and mothers with biomarker data is sensible.

\section{Limitations}

Lack of a consistent data collection tool introduces heterogeneity between studies used in this analysis, with respect to information on the exposure of interest. Additionally, data on ETS exposure is measured with varying levels of detail, and in one case, ETS is not measured. The studies used have heterogeneous populations with respect to age, ethnicity, and geographical regions. Sampling also differs in the studies selected and may compromise the external validity of the findings. Only two studies collected information on hair colour, a known confounder of the relationship between exposure to ETS and hair cotinine levels. Classification of individuals in the three exposure groups: active smokers, passive smokers and unexposed non-smokers, relies on self-reports, which may result in case misclassification. Lack of segmental hair analysis results in an inability to match hair cotinine levels to a specific exposure period. However, all hair samples were collected from the scalp and thus the exposure measured has occurred recently, within the past three months prior to interview. Error associated with hair collection also exists. 
Biomarker measurement is another source of errors and includes errors in laboratory methods, errors due to omissions in the protocol, and errors due to variation in the execution of the protocol. Irregular hair growth and use of hair treatments have not been assessed and may influence study results.

\section{Future Directions}

The validation of any biomarker is an empirical process that involves the gradual accumulation of evidence supporting the usefulness, accuracy and reliability of that biomarker. This process encompasses the ongoing validation of laboratory techniques, quality assurance, assessment of exposure-dose and dose-response relationships. Validation is also study specific, and the accuracy of a test must be evaluated in the context in which the test is being administered. The future validation of hair cotinine as a biomarker of ETS exposure will need to establish mean values in the general population, as well as in specific subpopulations. Factors known to be associated with hair cotinine concentrations need to be accounted for in these future analyses. These include hair color, hair treatments, ethnicity, age, use of nicotine replacement products, and asthma status. Studies have been carried out on asthmatic children $(22,32)$ (Williams et al., Rankin et al., Yolton et al. in progress) and these could form the basis of an investigation into benchmarking hair cotinine in this particular group of asthmatic children.

A clear dose-response relationship needs to be investigated in the general population, as well as among children, the elderly and among males and females separately. The relationship between fetal and maternal hair cotinine needs further elucidation, and studies should focus on exposure due to active versus passive maternal smoking.

In addition to its practical uses in the clinic, hair cotinine validation holds promise for the research community. Future studies can look at establishing equivalence formulas between hair cotinine and cotinine from other matrices. Currently the equivalence between saliva, blood and urine is 5:5:1. Knowledge on what this equivalence is for hair cotinine would be useful for comparing studies that measure hair cotinine with studies measuring cotinine from other sources. It would also be of use to further validate this biomarker by making it comparable to others.

Cut-off values discriminating unexposed non-smokers from passive and from active smokers need to be quantified and tested in the general population as well as in specific sub-populations.

Future studies should focus on a more accurate quantification of ETS exposure, which should take into account space, ventilation, number of smokers and quantity of smoke in the proximity of the exposed individual. Only with an accurate measure of real ETS exposure can validation of biomarker data be reliable.

\section{Conclusions}

Hair cotinine provides a non-invasive, inexpensive, sensitive and accurate tool for evaluating the level of active smoking and exposure to ETS in a paediatric relevant population. The test has a superior performance in discriminating between active smokers and passive or unexposed. It has little informative value when distinguishing passively exposed from unexposed individuals. It is also most accurate in the population of pregnant women. The relationship between dose (number of cigarettes smoked per day) and hair cotinine exists but it is inconclusive. Adequate collection of information on smoking and ETS exposure is paramount for adequate quantification of hair cotinine in different exposure groups.

\section{Acknowledgements}

The authors wish to acknowledge Roberta Ferrence, Tom Einarson, Peter Selby, Philip Blanchette, the Ontario Graduate Scholarship fund, the Canadian Institute of Health Research, and the Ashley Studentship for research in tobacco control.

\section{References}

1. Health Canada. Canadian Tobacco Use Monitoring Survey (CTUMS): summary of results for wave 1 (February to June) of 2002. Ottawa: Health Canada, 2003: fact sheets.

2. J.R. DiFranza, C.A. Aligne, and M. Weitzman. Prenatal and postnatal environmental tobacco smoke exposure and children's health. Pediatrics. 113: 1007-1015 (2004).

3. J. Jinot,and S. Bayard. Respiratory health effects of exposure to environmental tobacco smoke. Rev Environ Health. 11: 89-100 (1996).

4. S.L. Stathis, D.M. O'Callaghan, G.M. Williams, J.M. Najman, M.J. Andersen, and W. Bor. Maternal cigarette smoking during pregnancy is an independent predictor for symptoms of middle ear disease at five years post-delivery. Pediatrics. 104: e16 (1999).

5. M. Weitzman, R.S. Byrd, C.A. Aligne, and M. Moss. The effects of tobacco exposure on children's behavioral and cognitive functioning: implications for clinical and public health policy and future research. Neurotoxicol Teratol. 24: 397-406 (2002).

6. D.P. Strachan, and D.G. Cook. Health effects of passive smoking. 4. Parental smoking, middle ear disease and adenotonsillectomy in children. Thorax. 53: 50-56 (1998).

7. Y. Chen, W. Li, and S. Yu. Influence of passive smoking on admissions for respiratory illness in early childhood. $\mathrm{Br}$ Med J (Clin Res Ed). 293: 303-306 (1986). 
8. W.K. Al-Delaimy. Hair as a biomarker for exposure to tobacco smoke. Tob Control. 11: 176-182 (2002).

9. S.L. Bramer, and B.A. Kallungal. Clinical considerations in study designs that use cotinine as a biomarker. Biomarkers. 8: 187-203 (2003).

10. EPA C. Proposed identification of environmental tobacco smoke as a toxic air contaminant. (2004).

11. C. Eliopoulos, J. Klein, and G. Koren. Validation of selfreported smoking by analysis of hair for nicotine and cotinine. Ther Drug Monit. 18: 532-536 (1996).

12. S. Pichini, I. Altieri, M. Pellegrini, R. Pacifici, and P. Zuccaro. The analysis of nicotine in infants' hair for measuring exposure to environmental tobacco smoke. Forensic Sci Int. 84: 253-258 (1997).

13. P. Kintz. Gas chromatographic analysis of nicotine and cotinine in hair. J Chromatogr. 580: 347-353 (1992).

14. P. Kintz, B. Ludes, and P. Mangin. Evaluation of nicotine and cotinine in human hair. J Forensic Sci. 37: 72-76 (1992).

15.H. Dimich-Ward, H. Gee, M. Brauer, and V. Leung. Analysis of nicotine and cotinine in the hair of hospitality workers exposed to environmental tobacco smoke. J Occup Environ Med. 39: 946-948 (1997).

16. W.K. Al-Delaimy, J. Crane, and A. Woodward. Questionnaire and hair measurement of exposure to tobacco smoke. J Expo Anal Environ Epidemiol. 10: 378-384 (2000)

17. G. Koren, J. Klein, R. Forman, K. Graham, and M.K. Phan. Biological markers of intrauterine exposure to cocaine and cigarette smoking. Dev Pharmacol Ther. 18: 228-236 (1992).

18.C. Eliopoulos, J. Klein, M.K. Phan, B. Knie, M. Greenwald, D. Chitayat, and G. Koren. Hair concentrations of nicotine and cotinine in women and their newborn infants. JAMA. 271: 621-623 (1994).

19. C. Eliopoulos, J. Klein, D. Chitayat, M. Greenwald, and G. Koren. Nicotine and cotinine in maternal and neonatal hair as markers of gestational smoking. Clin Invest Med. 19: 231-242 (1996).

20. E. Jacqz-Aigrain, D. Zhang, G. Maillard, D. Luton, J. Andre, and J.F. Oury. Maternal smoking during pregnancy and nicotine and cotinine concentrations in maternal and neonatal hair. BJOG 109: 909-911 (2002).

21. J.J. Langone, H.B. Gjika, and H. Van Vunakis. Nicotine and its metabolites. Radioimmunoassays for nicotine and cotinine. Biochemistry. 12: 5025-5030 (1973).

22. J.M. Knight, C. Eliopoulos, J. Klein, M. Greenwald, and G. Koren. Pharmacokinetic predisposition to nicotine from environmental tobacco smoke: a risk factor for pediatric asthma. J Asthma. 35: 113-117 (1998).

23. G. Koren. Measurement of drugs in neonatal hair; a window to fetal exposure. Forensic Sci Int. 70: 77-82 (1995).
24. M. Rebagliato, F. Bolumar, V. Florey Cdu, M.J. Jarvis, S. Perez-Hoyos, I. Hernandez-Aguado, and M.J. Avino. Variations in cotinine levels in smokers during and after pregnancy. Am J Obstet Gynecol. 178: 568-571 (1998).

25. G.A. Ellard, F. de Waard, and J.M. Kemmeren. Urinary nicotine metabolite excretion and lung cancer risk in a female cohort. Br J Cancer. 72: 788-791 (1995).

26. G.A. Ellard, F.D. Johnstone, R.J. Prescott, W. Ji-Xian, and M. Jian-Hua. Smoking during pregnancy: the dose dependence of birthweight deficits. Br J Obstet Gynaecol. 103: 806-813 (1996).

27.D.K. Hatsukami, S.S. Hecht, D.J. Hennrikus, A.M. Joseph, and P.R. Pentel. Biomarkers of tobacco exposure or harm: application to clinical and epidemiological studies. 25-26 October 2001, Minneapolis, Minnesota. Nicotine Tob Res. 5: 387-396 (2003).

28. L. Irvine, I.K. Crombie, R.A. Clark, P.W. Slane, K.E. Goodman, C. Feyerabend, and J.I. Cater. What determines levels of passive smoking in children with asthma? Thorax. 52: 766-769 (1997).

29. A.M. Preston, L.J. Ramos, C. Calderon, and H. Sahai. Exposure of Puerto Rican children to environmental tobacco smoke. Prev Med. 26: 1-7 (1997).

30. E. Kohler, V. Sollich, R. Schuster, and W. Thal. Passive smoke exposure in infants and children with respiratory tract diseases. Hum Exp Toxicol. 18: 212-217 (1999).

31.J.S. Torano, and H.J. van Kan. Simultaneous determination of the tobacco smoke uptake parameters nicotine, cotinine and thiocyanate in urine, saliva and hair, using gas chromatography-mass spectrometry for characterisation of smoking status of recently exposed subjects. Analyst. 128: 838-843 (2003).

32. M.D. Eisner, P.P. Katz, E.H. Yelin, S.K. Hammond, and P.D. Blanc. Measurement of environmental tobacco smoke exposure among adults with asthma. Environ Health Perspect. 109: 809-814 (2001).

33. M.S. Kramer, L. Goulet, J. Lydon, L. Seguin, H. McNamara, C. Dassa, R.W. Platt, M.F. Chen, H. Gauthier, J. Genest, S. Kahn, M. Libman, R. Rozen, A. Masse, L. Miner, G. Asselin, A. Benjamin, J. Klein, and G. Koren. Socio-economic disparities in preterm birth: causal pathways and mechanisms. Paediatr Perinat Epidemiol. (15) Suppl 2: 104-23 (2001).

34. S.I. Woodruff, T.L. Conway, C.C. Edwards, and M.F. Hovell. Acceptability and validity of hair collection from Latino children to assess exposure to environmental tobacco smoke. Nicotine Tob Res. 5: 375-85 (2003).

35. J.A. Groner, K. Ahijevych, L.K. Grossman, and L.N. Rich. The impact of a brief intervention on maternal smoking behavior. Pediatrics. 105: 267-71 (2000).

36. E. Jacqz-Aigrain, D. Zhang, G. Maillard, D. Luton, J. Andre, and J.F. Oury. Maternal smoking during pregnancy and nicotine and cotinine concentrations in maternal and neonatal hair. BJOG. 109: 909-11 (2002). 